CENDEKIA, Vol. 11, No. 2, Oktober 2017

p ISSN: 1978 2098; e ISSN: 2407 8557

Http://cendekia.pusatbahasa.or.id; Email: cendekiaoslo@gmail.com

Center of Language and Culture Studies, Surakarta, Indonesia

Azkiyah, Laili. 2017. Bibliokonseling Virtual: Metode Pengurangan

Tindak Pikiran Pornografi pada Siswa SMPN 1 Karangploso

Cendekia, (2017), 11(2): 183 194.

\title{
BIBLIOKONSELING VIRTUAL: METODE PENGURANGAN TINDAK PIKIRAN PORNOGRAFI PADA SISWA SMPN 1 KARANGPLOSO
}

\author{
Laili Azkiyah \\ SMP Negeri 1 Karangploso \\ Jalan PB. Sudirman 49 Karangploso \\ lailiazkiyah21@gmail.com
}

\begin{abstract}
This classroom action research explores the use of virtual biblicouncelling to reduce the acts on pornography abuses to SMPN 1 Karangploso Malang. This study was implemented in two cycles each of which was defined in four steps: planning, acting, observing, and reflection. The results showed that the implications of changes in the status of the superego is more robust to reduce acts of pornography. Students are gradually able to control the acts of pornographic thoughts including: imagery porn actions and matters that deal with pornographic actions, pornographic images or videos or to do so with the guidance of the group and virtual bibliocouncelling approach.
\end{abstract}

Keywords: virtual bibliokonseling, pornography, group counseling

Perkembangan teknologi dan informasi sangat pesat. Hal ini membawa dampak positif maupun negatif. Dampak positif tentu memperluas jaringan dan informasi yang tak terbatas. Kemudahan akses internet mempermudah siswa mencari beragam informasi untuk menyelesaikan tugas dan sebagai sarana belajar mandiri. Sementara itu, dampak negatif terkait kecanggihan internet dalam handphone perlu diwaspadai. Siswa mudah mengakses gambar, video, maupun informasi-informasi yang berbau pornografi. Padahal, pornografi sangat merusak otak. Menurut Hilton (dalam mediaindonesia.com, 2017) menyebutkan bahwa anatomi otak orang yang sering terpapar pornografi akan berubah. Ada cacat di otaknya yang membuat orang tersebut terus-menerus mengejar hal-hal sensual dan erotis. Level ketagihannya setara dengan ketagihan kokaina, narkoba yang sangat poten kekuatannya.

Kerusakan otak tentu merusak konsentrasi dan daya pikir siswa. Menurut Kastlemaan (2010) pornografi dapat menyebabkan kerusakan pada lima bagian otak, terutama pada Pre Frontal Corteks (bagian otak yang tepat berada di belakang dahi), sedangkan kecanduan narkoba menyebabkan kerusakan pada tiga bagian otak. Kerusakan bagian otak ini akan membuat prestasi akademik menurun, orang tidak bisa membuat perencanaan, mengendalikan hawa nafsu dan emosi, mengambil keputusan dan berbagai peran eksekutif otak sebagai pengendali impuls-impuls. Hal ini dikarenakan bagian ini yang membedakan manusia dengan binatang. Pada pecandu pornografi otak akan merangsang produksi dopamin dan endorfin, yaitu suatu bahan kimia otak yang membuat rasa senang dan merasa lebih baik. Dalam kondisi normal, 
CENDEKIA, Vol. 11, No. 2, Oktober 2017

p ISSN: 1978 2098; e ISSN: 2407 8557

Http://cendekia.pusatbahasa.or.id; Email: cendekiaoslo@gmail.com

Center of Language and Culture Studies, Surakarta, Indonesia

Azkiyah, Laili. 2017. Bibliokonseling Virtual: Metode Pengurangan

Tindak Pikiran Pornografi pada Siswa SMPN 1 Karangploso

Cendekia, (2017), 11(2): 183 194.

zat-zat ini akan sangat bermanfaat untuk membuat orang sehat dan menjalankan hidup dengan lebih baik. Namun dengan pornografi, otak akan mengalami hyper stimulating (rangsangan yang berlebihan) sehingga otak akan bekerja dengan sangat ekstrem kemudian mengecil dan rusak. Kastlemaan (2010) juga menjelaskan bahwa pornografi merupakan adiksi baru yang tidak tampak pada mata, tidak terdengar oleh telinga, namun menimbulkan kerusakan otak yang permanen bahkan melebihi kecanduan narkoba. Oleh karena itu, diperlukan suatu pembinaan dan pengawasan dari semua kalangan, khususnya untuk anak-anak, remaja dan dewasa muda agar bisa terhindar dari bahaya kecanduan baru, yaitu pornografi.

Bimbingan dan Konseling (BK) berperan penting dalam pembinaan perilaku siswa di sekolah. Bimbingan adalah proses pemberian bantuan (proses of helping) kepada individu agar mampu memahami dan menerima diri dan lingkungannya, mengarahkan diri dan menyesuaikan diri secara positif dan konstruktif terhadap tuntutan norma kehidupan (agama dan budaya) sehingga mencapai kehidupan yang bermakna (Damayanti, 2012:9). Sementara itu, konseling adalah proses pemberian bantuan yang dilakukan melalui wawancara konseling seorang ahli yang diisebut konselor kepada individu yang sedang mengalami suatu masalah yang bermuara pada teratasinya masalah yang dihadapi oleh klien (Prayitno, 2004:105).

Bimbingan dan konseling tidak hanya berorientasi untuk mengatasi permasalahan kesulitan belajar siswa, tetapi BK juga dapat menyentuh aspek perilaku atau akhlak siswa dalam proses pembentukan kepribadian. Pembentukan kepribadian inilah yang menentukan siswa menjadi manusia yang taat atau cenderung menyimpang dari aturan. Ada manusia yang sanggup mampu mengatasi persoalan tanpa bantuan dari pihak lain, tetapi tidak sedikit manusia yang tidak mampu mengatasi persoalan bila tidak dibanntu orang lain, maka dari inilah bimbingan konseling dibutuhkan (Walgito, 2010:10).

Bimbingan dan konseling merupakan salah satu komponen dari pendidikan. Bimbingan dan konseling adalah suatu kegiatan bantuan dan tuntunan yang diberikan kepada individu pada umumnya, dan siswa pada khususnya di sekolah. Hal ini sangat relevan jika dilihat dari rumusan bahwa pendidikan adalah usaha sadar yang bertujuan mengembangkan kepribadian dan potensi-potensi (bakat, minat, dan kemampuan). Kepribadian menyangkut masalah prilaku atau sikap mental dan kemampuan meliputi masalah akademik dan keerampilan. Tingkat kepribadian dan kemampuan yang dimiliki oleh seseorang merupakan suatu gambaran mutu dari orang bersangkutan (Sukardi, 2007:1).

Siswa sebagai bagian warga sekolah memerlukan interaksi dan sosialisasi dengan warga sekolah dan masyarakat. Untuk itu, siswa harus disiapkan mengembangkan ketentuan yang mengatur hak dan kewajiban masing-masing individu sebagai anggota di sekolah maupun di masyarakat. Ketentuan-ketentuan itu berupa seperangkat nilai, norma sosial, maupun pandangan hidup yang terpadu dalam sistem budaya yang berfungsi sebagai rujukan hidup (Prayitno, 1999:169).

Berdasarkan studi pendahuluan, ada beberapa temuan berkaitan dengan tindak pornografi. Beberapa tindak yang termasuk kategori pornografi antara lain (1) melihat 
CENDEKIA, Vol. 11, No. 2, Oktober 2017

p ISSN: 1978 2098; e ISSN: 2407 8557

Http://cendekia.pusatbahasa.or.id; Email: cendekiaoslo@gmail.com

Center of Language and Culture Studies, Surakarta, Indonesia

Azkiyah, Laili. 2017. Bibliokonseling Virtual: Metode Pengurangan

Tindak Pikiran Pornografi pada Siswa SMPN 1 Karangploso

Cendekia, (2017), 11(2): 183 194.

gambar atau video porno, (2) membayangkan gambar/ adegan porno, (3) mengajak teman melihat gambar porno di majalah, (4) memperlihatkan gambar porno kepada teman, (5) mengirimkan gambar atau video porno, (6) membicarakan topik-topik pornografi, dan (7) mengkhayalkan membuat tindak pornografi, (8) melakukan tindak pornografi. Studi pendahuluan ini dilakukan terhadap 30 siswa. Sebanyak 10 siswa menyatakan bahwa melakukan tindakan (1) - (7) dengan kategori sering, 11 siswa menyatakan melakukan tidakan (1) - (7) dengan kategori jarang, 8 siswa menyatakan tidak pernah, dan 1 siswa menyatakan melakukan tindakan (8).

Salah satu pendekatan yang digunakan dalam mengurangi tindak pikiran pornografi yaitu pendekatan bibliokonseling virtual. Bibliokonseling merupakan salah satu teknik pemecahan masalah yang menggunakan konsep, strategi tertulis dan sarana informasi tertulis lainnya sebagai pengganti konselor atau guru BK (Bisri, 2010). Teknik ini didasarkan pada teori-teori kognitif dan teori onformasi prosessing. Teori ini berasumsi bahwa perilaku manusia dipengaruhi oleh struktur dan organisasi kognitif manusia. Secara spesifik langsung memengaruhi tingkah laku manusia dalam peta pikiran.

Untuk mengubah perilaku manusia, hal terpenting adalah mengubah peta pikiran dengan cara memasukkan informasi ke dalam pikirannya. Orang mengalami masalah atau kesulitan karena tidak memiliki peta kognitif. Jika peta kognitif seseorang berubah, perilaku seseorang dengan sendirinya berubah. Untuk mengubah perilaku seseorang tidak perlu memaksa atau menyuruh orang berubah, tetapi memberi informasi yang relevan dengan kebutuhan orang tersebut untuk berubah (Bisri, 2010). Oleh karena itu, memasukkan informasi dan konsep-konsep yang benar mengenai moral dan tindak pikiran pornografi secara tepat kepada siswa diharapkan mampu mengurangi tindak pikiran siswa terhadap pornografi.

Layanan bibliokonseling virtual masuk pada ranah id, ego, dan superego. Menurut Freud (1916) menyatakan bahwa tingkah laku manusia dikendalikan oleh dorongan-dorongan yang tidak disadarinya yang bersifat insting disebut id. Ekspresi id yang paling menonjol adalah penyaluran dorongan seks sebagai perwujudan dari prinsip mencari kesenangan sekaligus menjauhi kesakitan. Ego dikuasai prinsip kenyataan. Tujuan prinsip kenyataan adalah menangguhkan atau menahan ketegangan hingga mereda dengan bentuk kelakuan yang wajar. Superego adalah wakil kepribadian dari ukuran-ukuran norma dan cita-cita. Tujuan utama superego yaitu mengontrol dan mengatur gerak hati.

Layanan bibliokonseling virtual ini diadukan dengan layanan bimbingan kelompok. Sukardi (2008:64) juga menyatakan bahwa layanan bimbingan kelompok adalah layanan bimbingan yang memungkinkan sejumlah peserta didik secara bersamasama memperoleh berbagai bahan dari narasumber tertentu (terutama dari pembimbing/ konselor) yang berguna untuk menunjang kehidupan sehari-hari baik individu maupun sebagai pelajar, anggota keluarga dan masyarakat serta untuk mempertimbangkan dalam pengembilan keputusan. Tujuan bimbingan kelompok adalah memberikan kesempatankesempatan pada siswa belajar hal-hal penting yang berguna bagi pengarahan dirinya yang berkaitan dengan masalah pendidikan, pekerjaan, pribadi dan sosial, memberikan 
CENDEKIA, Vol. 11, No. 2, Oktober 2017

p ISSN: 1978 2098; e ISSN: 2407 8557

Http://cendekia.pusatbahasa.or.id; Email: cendekiaoslo@gmail.com

Center of Language and Culture Studies, Surakarta, Indonesia

Azkiyah, Laili. 2017. Bibliokonseling Virtual: Metode Pengurangan

Tindak Pikiran Pornografi pada Siswa SMPN 1 Karangploso

Cendekia, (2017), 11(2): 183 194.

layanan-layanan penyembuhan melalui kegiatan kelompok, untuk mencapai tujuantujuan bimbingan secara lebih ekonomis dan efektif dari pada melalui kegiatan bimbingan individual, serta untuk melaksanakan layanan konseling individual secara lebih efektif (Romlah, 2003:14-15).

Berdasarkan uraian tersebut, peneliti mengadakan penelitian untuk mengkaji seberapa besar pengaruh pendekatan bibliokonseling virtual dalam mengurangi tindak pikiran pornografi siswa. Peneliti mengadakan penelitian dengan judul "Pengurangan Tindak Pikiran Pornografi Menggunakan Pendekatan Bibliokonseling Virtual dengan Metode Bimbingan Kelompok bagi Siswa SMPN 1 Karangploso”.

\section{METODE}

Jenis penelitian ini menggunakan penelitian tindakan kelas. Setiap siklus terdiri dari empat tahapan, yaitu: perencanaan tindakan, pelaksanaan tindakan, observasi/evaluasi, dan refleksi (Kemmis dan Mc. Taggart, 1998). Kehadiran peneliti di lapangan bersifat wajib. Pada penelitian kualitatif, peneliti sendiri atau dengan bantuan orang lain merupakan alat pengumpul data utama (Moleong, 2007:9). Peneliti berperan sebagai perencana, pelaksana, pengumpul data, penganalisis data, penafsir data, dan pada akhirnya peneliti menjadi pelapor hasil penelitian. Penelitian ini dilakukan di SMP Negeri 1 Karangploso. Subjek penelitian yaitu siswa kelas IX SMP N 1 Karangploso tahun pelajaran 2012/2013 sebanyak 11 siswa yang benar-benar mengalami tindak pikiran pornografi. Sumber data diperoleh dari hasil individu dalam memahami konsep moral dan pornografi. Penelitian dilakukan dalam dua siklus.

Data yang dikumpulkan dalam penelitian ini berupa (1) hasil observasi selama proses pembelajaran yang berpedoman pada lembar observasi, (2) hasil tes, (3) dokumentasi. Perangkat pembelajaran yang digunakan adalah RPPBK dan Lembar kerja siswa. Data hasil observasi yang dilakukan dianalisis dengan memberikan skor untuk penentuan kategori.

Indikator keberhasilan dalam penelitian ini yaitu meningkatnya hasil belajar siswa kelas IX SMPN 1 Karangploso tahun pelajaran 2012/2013 pada pemahaman siswa terhadap konsep moral dan tindak pikir pornografi. Indikator ketuntasan belajar $\geq$ 75\% dari jumlah seluruh siswa. Data hasil observasi yang dilakukan dianalisis dengan memberikan skor untuk penentuan kategori.

$$
\text { Persentase keberhasilan }=\frac{\sum \text { Deskriptor yang muncul }}{\sum \text { Deskriptor maksimal }} \times 100 \%
$$

Hasil perhitungan persentase keberhasilan tindakan pada masing-masing tahapan pembelajaran yang diperoleh akan dibandingkan dengan penentuan skor pemahaman siswa dengan klasifikasi pada tabel berikut ini (Purwanto, 2008:103). 
CENDEKIA, Vol. 11, No. 2, Oktober 2017

p ISSN: 1978 2098; e ISSN: 2407 8557

Http://cendekia.pusatbahasa.or.id; Email: cendekiaoslo@gmail.com Center of Language and Culture Studies, Surakarta, Indonesia

Azkiyah, Laili. 2017. Bibliokonseling Virtual: Metode Pengurangan Tindak Pikiran Pornografi pada Siswa SMPN 1 Karangploso Cendekia, (2017), 11(2): 183 194.

Tabel 1 Penentuan Tingkat Pemahaman Siswa

\begin{tabular}{llll}
\hline Persentase & Nilai & Bobot & Predikat \\
\hline $86 \%-100 \%$ & A & 4 & Sangat Baik \\
\hline $76 \%-85 \%$ & B & 3 & Baik \\
\hline $60 \%-75 \%$ & C & 2 & Cukup \\
\hline $55 \%-69 \%$ & D & 1 & Kurang \\
\hline $0 \%-54 \%$ & E & 0 & Sangat Kurang \\
\hline
\end{tabular}

Data hasil tes siswa dianalisis dengan membandingkan persentase ketuntasan secara klasikal pada penerapan pendekatan bibliokonseling virtual siklus I dan siklus II. Sementara itu, persentase ketuntasan belajar secara klasikal dihitung dengan cara membandingkan jumlah siswa yang mencapai ketuntasan belajar dengan jumlah siswa secara keseluruhan (siswa maksimal) kemudian dikalikan $100 \%$.

Persentase ketuntasan belajar klasikal $=\frac{\sum \text { Deskriptor yang muncul }}{\sum \text { Deskriptor maksimal }} \times 100 \%$

Data hasil dokumentasi yang diperoleh berupa foto-foto selama kegiatan pembelajaran berlangsung. Dokumentasi foto ini digunakan sebagai gambaran konkret aktivitas-aktivitas pembelajaran yang terjadi di dalam kelas. Prosedur penelitian dapat digambarkan dalam skema berikut.

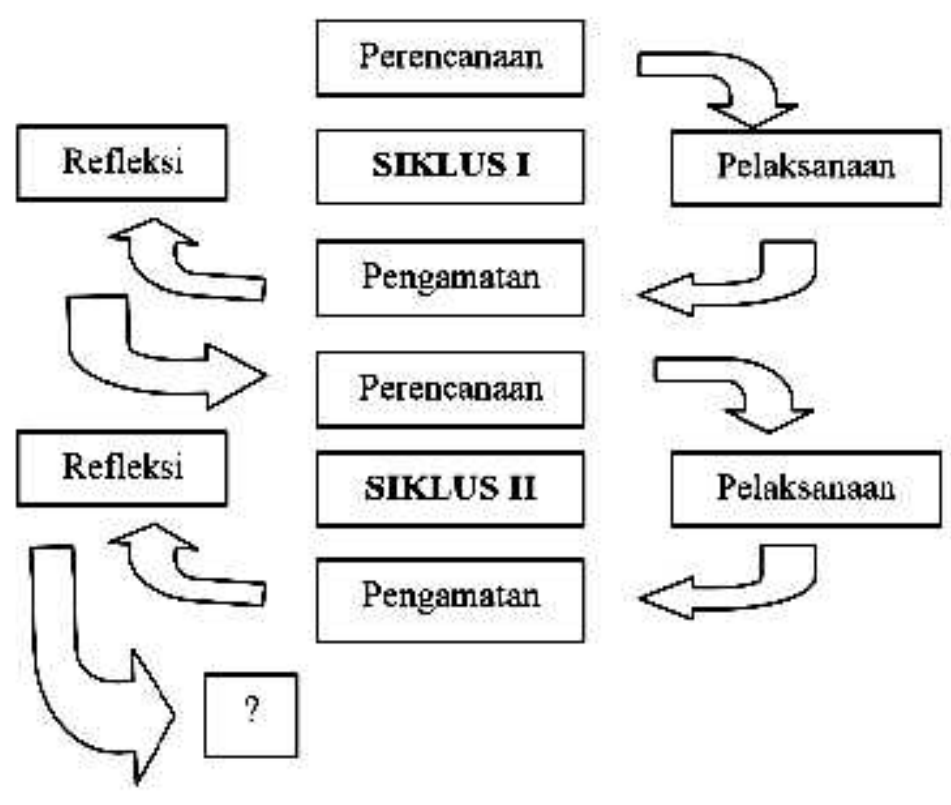

Berdasarkan bagan prosedur penelitian, setiap siklus melalui empat tahap yaitu perencanaan, pelaksanaan, observasi dan refleksi. Pada pelaksanaan tindakan kelas menggunakan pendekatan bibliokonseling virtual dengan bimbingan kelompok ini mengacu pada tahap-tahap bimbingan kelompok yang dikemukakan oleh Prayitno (1995:40) bimbingan kelompok yang meliputi empat tahap yang sebelumnya diawali 
CENDEKIA, Vol. 11, No. 2, Oktober 2017

p ISSN: 1978 2098; e ISSN: 2407 8557

Http://cendekia.pusatbahasa.or.id; Email: cendekiaoslo@gmail.com

Center of Language and Culture Studies, Surakarta, Indonesia

Azkiyah, Laili. 2017. Bibliokonseling Virtual: Metode Pengurangan

Tindak Pikiran Pornografi pada Siswa SMPN 1 Karangploso

Cendekia, (2017), 11(2): 183 194.

dengan tahap permulaan atau tahap awal untuk mempersiapkan anggota kelompok. Tahap-tahap tersebut yaitu tahap pembentukan, tahap peralihan, tahap kegiatan, dan tahap pengakhiran.

1) Tahap I (Pembentukan)

Tahap ini merupakan tahap pengenalan, tahap perlibatan diri atau tahap memasukkan diri ke dalam kehidupan suatu kelompok. Pada tahap ini para anggota saling memperkenalkan diri dan juga mengungkapkan tujuan atau harapan-harapan yang ingin dicaapai baik oleh masing-masing, sebagian, maupun seluruh anggota. Dalam tahap ini anggota kelompok mulai belajar untuk terlibat dalam interaksi kelompok. Menurut Prayitno (1995:44) kegiatan-kegiatan yang harus dilakukan pada tahap awal, adalah mengungkapkan pengertian dan tujuan kegiatan konseling kelompok, menjelaskan cara-cara dan asas-asas kegiatan bimbingan kelompok, saling memperkenalkan dan mengungkapkan diri, permainan pengakraban. Selain itu, mengajarkan kepada anggota dasar hubungan antarmanusia seperti mendengarkan dan menanggapi dengan aktif.

\section{2) Tahap II (Peralihan)}

Tahap kedua, tahap peralihan atau transisi. Pada tahap ini suasana kelompok mulai terbentuk dan dinamika kelompok sudah mulai tumbuh. Menurut Prayitno (1995:47) kegiatan-kegiatan yang harus dilakukan pada tahap ini adalah menjelaskan kegiatan yang akan ditempuh pada tahap berikutnya, menawarkan atau mengamati apakah para anggota sudah siap menjalani kegiatan pada tahap selanjutnya (tahap ketiga), membahas suasana yang terjadi, meningkatkan kemampuan keikutsertaan anggota, kalau perlu kembali ke beberapa aspek tahap pertama (tahap pembentukan).

\section{3) Tahap III (Kegiatan)}

Tahap ini merupakan inti kegiatan kelompok sehingga aspek-aspek yang menjadi isi pengiringnya cukup banyak. Pada kegiatan ini saatnya anggota berpartisiasi untuk menyadari bahwa merekalah yang bertanggung jawab atas kehidupan mereka. Kegiatan-kegiatan yang harus dilakukan pada tahap ini, adalah masing-masing anggota secara bebas menemukakan pendapat terhadap topik atau masalah, menetapkan topik atau masalah yang akan dibahas terlebih dahulu, anggota membahas masing-masing topik atau masalah secara mendalam dan tuntas, kegiatan selingan. Pada tahap ini, peneliti memasukkan layanan bibliokonseling virtual agar diskusi kelompok tidak melebar.

\section{4) Tahap IV (Pengakhiran)}

Tahap keempat adalah tahap akhir yang merupakan konsolidasi dan terminasi. Pada tahap ini "pokok perhatian utama bukanlah pada beberapa kali kelompok itu harus bertemu namun pada hasil yang telah dicapai oleh kelompok ketika menghentikan pertemuan (Prayitno, 1995: 58). Pada saat kelompok memasuki tahap pengakhiran, kegiatan kelompok sebaiknya dipusatkan pada pembahasan tentang apakah anggota 
CENDEKIA, Vol. 11, No. 2, Oktober 2017

p ISSN: 1978 2098; e ISSN: 2407 8557

Http://cendekia.pusatbahasa.or.id; Email: cendekiaoslo@gmail.com

Center of Language and Culture Studies, Surakarta, Indonesia

Azkiyah, Laili. 2017. Bibliokonseling Virtual: Metode Pengurangan

Tindak Pikiran Pornografi pada Siswa SMPN 1 Karangploso

Cendekia, (2017), 11(2): 183 194.

kelompok akan mampu menerapkan hal-hal yang telah dipelajari pada kehidupan anggota sehari-hari.

\section{HASIL DAN BAHASAN}

\section{Hasil Pendekatan Bibliokonseling Virtual Siklus I}

Pelaksanaan bimbingan dilakukan dengan tanya jawab mengenai pemahaman siswa terhadap tindak pornografi secara umum serta dampaknya bagi siswa. Hal ini dilakukan untuk mengetahui pendapat siswa tentang tindak pornografi, munculnya keterbukaan, tidak resisten. Kemudian, peneliti memberi kesempatan kelompok lain untuk memberikan tanggapan dan saran terhadap contoh dampak tindak pornografi. Peneliti memberikan informasi awal terkait tindak pornografi beserta dampaknya. Proses pemberian informasi inilah yang dimaksud pendekatan bibliokonseling virtual. Peneliti memberikan data yang benar terkait materi yang dibahas. Kemudian, siswa mendiskusikan tindak pornografi berdasarkan pertanyaan peneliti. Setelah itu, siswa merangkum informasi berdasarkan lembar kerja siswa yang dibagikan peneliti. Lembar kerja ini telah disesuaikan dengan konteks bimbingan bibliokonseling virtual.

Kondisi pemahaman awal siswa mengenai konsep moral dan tindak pornografi sangat minim. Hal ini dapat dilihat pada hasil siswa pada lembar konseling. Perhatikan tabel berikut.

Tabel 2 Pemahaman Siswa Terhadap Konsep Moral Siklus I

\begin{tabular}{lllll}
\hline Persentase & Nilai & Bobot & Predikat & Jumlah Siswa \\
\hline $86 \%-100 \%$ & A & 4 & Sangat Baik & 0 \\
\hline $76 \%-85 \%$ & B & 3 & Baik & 6 \\
\hline $60 \%-75 \%$ & C & 2 & Cukup & 3 \\
\hline $55 \%-69 \%$ & D & 1 & Kurang & 2 \\
\hline $0 \%-54 \%$ & E & 0 & Sangat Kurang & 0 \\
\hline
\end{tabular}

Berdasarkan tabel tersebut, hasil lembar kerja siswa menunjukkan ada 6 siswa yang mengetahui konsep moral dan tindak pikiran pornografi dengan baik. Ada 3 siswa yang cukup memahami konsep, 2 siswa kurang memahami konsep, dan tidak ada siswa yang tidak memahami konsep.

Setelah mendapat bimbingan bibliokonseling virtual, ada sedikit perubahan pada hasil angket. Berdasarkan 11 subjek yang dijadikan sumber data penelitian diperoleh 4 siswa yang mengalami penurunan tindak pornografi secara signifikan, sedangkan 7 siswa lainnya masih dalam kondisi labil dan belum banyak perubahan. Perhatikan grafik hasil siklus I berikut. 


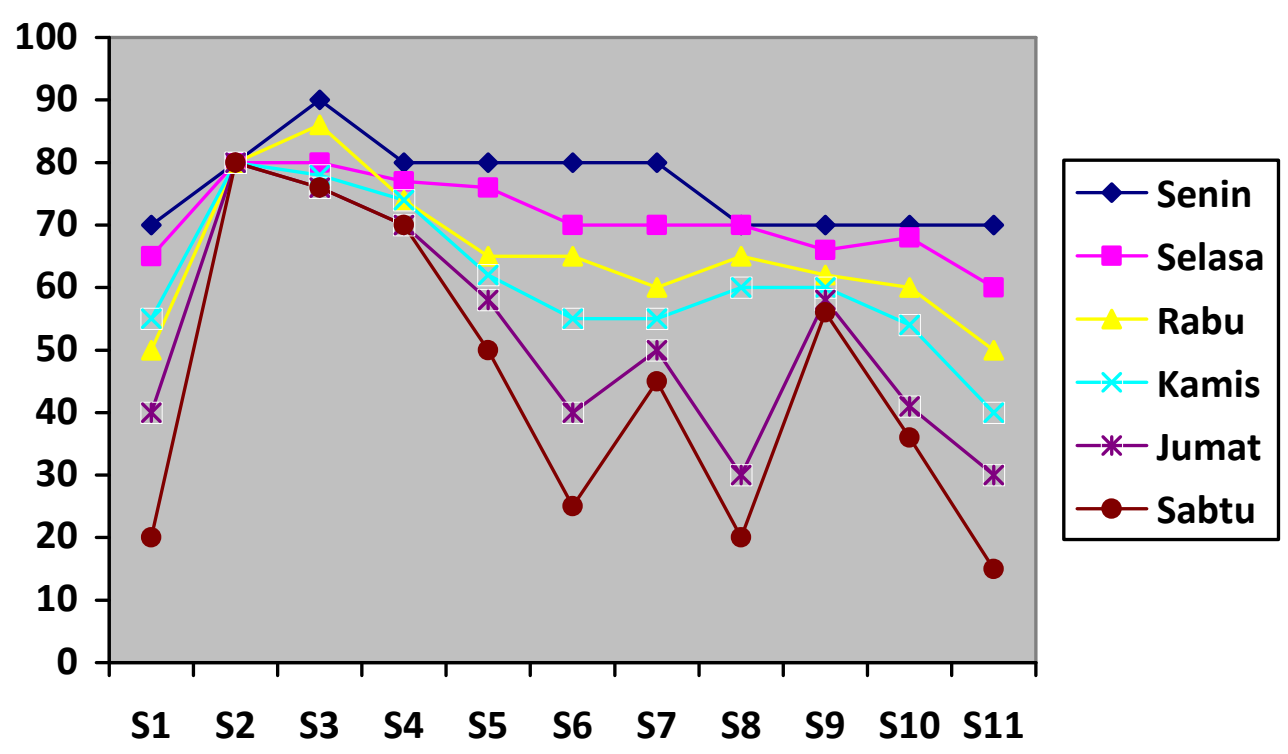

Berdasarkan grafik tersebut, S1-S6-S8-S11 mengalami penurunan hingga level bawah. S2 masih belum berubah. S3 dan S4 hanya mengalami sedikit penurunan. S5S7-S9 mengalami penurunan, tetapi masih termasuk pada level tinggi. Berdasarkan hasil angket dan observasi, beberapa hal yang memengaruhi kecilnya perubahan ini dikarenakan (1) adanya dorongan rasa ingin tahu subjek yang sangat kuat, (2) subjek belum sepenuuhnya memahami tindak pornografi secara kultural sebagai tindak negatif, (3) subjek belum memiliki kontrol diri yang memadai dalam mengendalikan dorongan seksual, (4) materi bibliokonseling virtual belum memadai. Berdasarkan hasil tersebut, perlu dilakukan tindakan siklus II.

\section{Hasil Pendekatan Bibliokonseling Virtual Siklus II}

Pelaksanaan bimbingan kelompok dengan pendekatan bibliokonseling virtual pada siklus II hampir sama dengan pelaksanaan pada siklus I. Perbedaan terletak pada materi layanan bibliokonseling virtual. Materi pada siklus I hanya mengarah pada sanksi-sanksi di sekolah maupun di lingkungan masyarakat. Sementara itu, pada siklus II dikaitkan dengan penggunaan Al-Quran dan Hadis. Selain itu, diperlihatkan beberapa dampak buruk otak yang terkena pornografi tingkat tinggi.

Langkah selanjutnya siswa berdiskusi dalam kelompok dan memperoleh layanan bibliokonseling virtual dari peneliti. Kemudian, siswa mendiskusikan tindak pornografi berdasarkan pertanyaan peneliti. Setelah itu, siswa merangkum informasi berdasarkan lembar kerja siswa yang dibagikan peneliti. Lembar kerja ini telah disesuaikan dengan konteks bimbingan bibliokonseling virtual.

Kondisi pemahaman siswa mengenai konsep moral dan tindak pornografi sangat baik. Hal ini dapat dilihat pada hasil siswa pada lembar konseling. Perhatikan tabel berikut. 
CENDEKIA, Vol. 11, No. 2, Oktober 2017

p ISSN: 1978 2098; e ISSN: 2407 8557

Http://cendekia.pusatbahasa.or.id; Email: cendekiaoslo@gmail.com

Center of Language and Culture Studies, Surakarta, Indonesia

Azkiyah, Laili. 2017. Bibliokonseling Virtual: Metode Pengurangan

Tindak Pikiran Pornografi pada Siswa SMPN 1 Karangploso

Cendekia, (2017), 11(2): 183 194.

Tabel 2 Pemahaman Siswa Terhadap Konsep Moral Siklus II

\begin{tabular}{llllc}
\hline Persentase & Nilai & Bobot & Predikat & Jumlah Siswa \\
\hline $86 \%-100 \%$ & A & 4 & Sangat Baik & 7 \\
\hline $76 \%-85 \%$ & B & 3 & Baik & 4 \\
\hline $60 \%-75 \%$ & C & 2 & Cukup & 0 \\
\hline $55 \%-69 \%$ & D & 1 & Kurang & 0 \\
\hline $0 \%-54 \%$ & E & 0 & Sangat Kurang & 0 \\
\hline
\end{tabular}

Berdasarkan tabel tersebut, hasil lembar kerja siswa menunjukkan seluruh siswa telah memahami konsep moral dan tindak pikiran pornografi dengan baik. Ada 7 siswa yang sangat baik dalap memahami konsep dan 4 siswa baik dalam memahami konsep moral dan tindak pikiran pornografi.

Setelah mendapat bimbingan bibliokonseling virtual, terjadi perubahan yang signifikan. Berdasarkan 11 subjek yang dijadikan sumber data penelitian diperoleh 9 siswa mengalami penurunan tindak pornografi secara signifikan hingga pada level bawah dan 2 siswa secara sadar berubah dan mencapai titik nol. Perhatikan grafik hasil siklus II berikut.

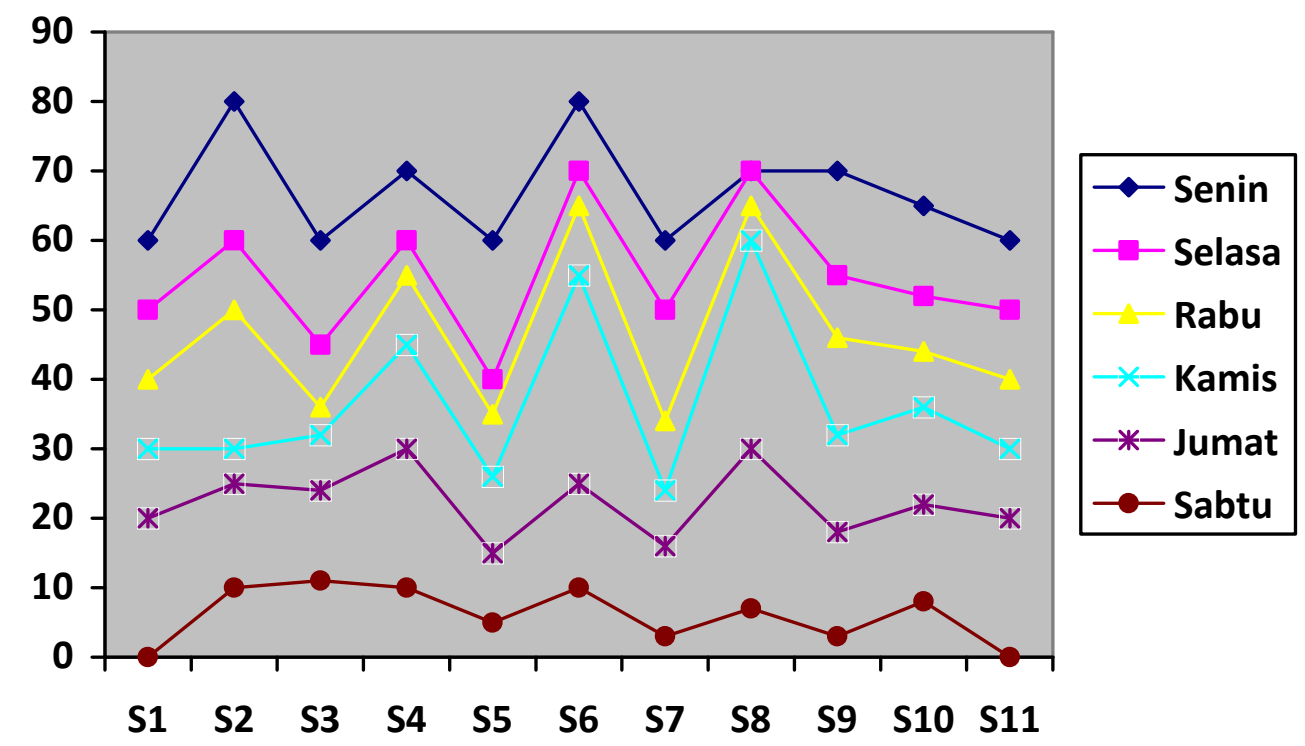

Berdasarkan grafik tersebut, $\mathrm{S} 1$ - S11 telah mencapai penurunan tindak pikiran pornografi hingga titik nol. Sementara itu, S2 - S3 - S4 - S5 - S6 - S7 - S8 - S 9 - S10 mengalami penurunan hingga level bawah $(<10)$. Berdasarkan hasil angket dan observasi, beberapa hal yang memengaruhi besarnya perubahan ini dikarenakan (1) adanya pemahaman yang benar subjek terhadap konsep moral dan dampak pornografi, (2) subjek memiliki kesadaran tinggi untuk berubah, (3) subjek memiliki kontrol diri 
CENDEKIA, Vol. 11, No. 2, Oktober 2017

p ISSN: 1978 2098; e ISSN: 2407 8557

Http://cendekia.pusatbahasa.or.id; Email: cendekiaoslo@gmail.com

Center of Language and Culture Studies, Surakarta, Indonesia

Azkiyah, Laili. 2017. Bibliokonseling Virtual: Metode Pengurangan

Tindak Pikiran Pornografi pada Siswa SMPN 1 Karangploso

Cendekia, (2017), 11(2): 183 194.

yang memadai dalam mengendalikan dorongan seksual karena takut berdosa, (4) materi bibliokonseling virtual telah memadai dan dilengkapi data dan fakta, video. Sebagaimana pendapat Prayitno (1995:178) bahwa bimbingan kelompok bertujuan untuk mendorong seseorang berbicara di muka orang banyak; mengeluarkan pendapat, ide, saran, tanggapan, perasaan; belajar menghargai pendapat orang lain, bertanggung jawab atas pendapat yang dikemukakannya; dan mengendalikan diri dan menahan emosi (gejolak kejiwaan yang bersifat negatif), dapat bertenggang rasa, menjadi akrab satu sama lainnya, membahas masalah atau topik-topik umum yang dirasakan atau menjadi kepentingan bersama.

Ego yang sebelumnya banyak melaksanakan dorongan id untuk bertindak porno menurun setelah siswa berhasil memperluas dan memperdalam nilai-nilai moralnya secara bertahap. Ego terpengaruh oleh tuntutan superego agar siswa bertindak berdasarkan nilai moral sehingga siswa dapat bertindak lebih proporsional dan lebih bertanggung jawab.

Implikasi perubahan status superego yang lebih kokoh bagi penurungan tindak pornografi semakin jelas. Siswa secara berangsur-angsur mampu mengendalikan tindak pornografi baik berpikir porno, membayangkan tindakan porno, membicarakan topik pornografi, melihat gambar atau video porno atau melakukannya.

\section{SIMPULAN}

Berdasarkan hasil dan pembahasan, peneliti dapat menyimpulkan beberapa hal antara lain (1) pendekatan bibliokonseling virtual dapat digunakan untuk mengurangi tindak pikiran pornografi siswa, (2) pendekatan bibliokonseling virtual dapat dipadukan dengan layanan bimbingan kelompok, (3) pengurangan tindak pikiran pornografi dapat dilakukan dengan layanan bimbingan kelompok menggunakan pendekatan bibliokonseling virtual. Hal ini didasarkan pada hasil siklus I dan siklus II. Pada tingkat pemahaman konsep moral dan tindak pikiran pornografi hasil lembar kerja siswa menunjukkan ada 6 siswa yang mengetahui konsep moral dan tindak pikiran pornografi dengan baik. Ada 3 siswa yang cukup memahami konsep, 2 siswa kurang memahami konsep, dan tidak ada siswa yang tidak memahami konsep. Setelah mendapat bimbingan bibliokonseling virtual, ada sedikit perubahan pada hasil angket. Berdasarkan 11 subjek yang dijadikan sumber data penelitian diperoleh 4 siswa yang mengalami penurunan tindak pornografi secara signifikan, sedangkan 7 siswa lainnya masih dalam kondisi labil dan belum banyak perubahan.

Pada siklus II hasil lembar kerja siswa menunjukkan seluruh siswa telah memahami konsep moral dan tindak pikiran pornografi dengan baik. Ada 7 siswa yang cukup memahami konsep, 6 siswa kurang memahami konsep, dan 1 siswa sangat kurang dalam memahami konsep. Setelah mendapat bimbingan bibliokonseling virtual, terjadi perubahan yang signifikan. Berdasarkan 11 subjek yang dijadikan sumber data penelitian diperoleh 9 siswa mengalami penurunan tindak pornografi secara signifikan hingga pada level bawah dan 2 siswa secara sadar berubah dan mencapai titik nol. 
CENDEKIA, Vol. 11, No. 2, Oktober 2017

p ISSN: 1978 2098; e ISSN: 2407 8557

Http://cendekia.pusatbahasa.or.id; Email: cendekiaoslo@gmail.com

Center of Language and Culture Studies, Surakarta, Indonesia

Azkiyah, Laili. 2017. Bibliokonseling Virtual: Metode Pengurangan

Tindak Pikiran Pornografi pada Siswa SMPN 1 Karangploso

Cendekia, (2017), 11(2): 183 194.

\section{SARAN}

berikut.

Berdasarkan simpulan tersebut, peneliti memberikan beberapa saran sebagai

1. Hendaknya dalam layanan bimbingan konseling lebih menguatkan nilai-nilai moral sebagai sarana mengurangi tindak pikiran pornografi.

2. Dalam pelaksanaan layanan hendaknya guru BK memberikan layanan bimbingan kelompok maupun penggunaan pendekatan bibliokonseling virtual.

3. Seluruh pihak yang ada di sekolah diharapkan dapat menciptakan lingkungan pergaulan siswa yang kondusif dengan memanfaatkan fasilitas sarana dan prasarana sekolah (wifi sekolah untuk akses internet). Dengan memanfaatkan fasilitas sekolah dengan benar, diharapkan akhlak siswa dapat terbentuk.

\section{DAFTAR PUSTAKA}

Arikunto, Suharsimi. 1992. Prosedur Penelitian dan Pendekatan Praktik. Jakarta: Rineka Cipta.

Bisri, Mohammad. 2010. Pedoman Standar Pelayanan Bibliokonseling. Malang. UMN.

Damayanti. 2012. Buku Pintar Panduan Bimbingan Konseling. Yogyakarta: Araska

Haksasi.

Moloeng, J. Lexy. 2008. Metode Penelitian Kualitatif. Bandung: Rosdakarya

Prayitno Dan Erman A. 1999. Dasar- Dasar Bimbingan dan Konseling. Jakarta:

Rhineka Cipta.

Sukardi (1989). Pendekatan Konseling Karir Dalam Bimbingan Karir. Satu Pendahuluan. Jakarta: Ghalia Indonesia.

Tohirin. 2007. Bimbingan Konseling Sekolah Madrasah. Jakarta: Raja Grafindo Persada.

Hilton, Donald Jr. http://mediaindonesia.com/news/read/97569/pornografi-merusakotak/2017-03-22\#sthash.272r51dd.dpuf

Kastlemaan, Mark. 2010. Pornografi Lebih Merusak Daripada Narkoba. (Online) http://www.daarulfikribandung.com/artikel/Pornografi\%20Lebih\%20Merusak\% 20Daripada\%20Narkoba.pdf 
CENDEKIA, Vol. 11, No. 2, Oktober 2017

p ISSN: 1978 2098; e ISSN: 2407 8557

Http://cendekia.pusatbahasa.or.id; Email: cendekiaoslo@gmail.com Center of Language and Culture Studies, Surakarta, Indonesia

Azkiyah, Laili. 2017. Bibliokonseling Virtual: Metode Pengurangan Tindak Pikiran Pornografi pada Siswa SMPN 1 Karangploso Cendekia, (2017), 11(2): 183 194. 